\title{
FORUM KERUKUNAN UMAT BERAGAMA (FKUB) DALAM PENANAMAN SIKAP TASAMUH MASYARAKAT
}

\author{
Dediek Kurniawan \\ STIES Babussalam Jombang \\ Email : didiekkurniawan176@gmail.com
}

\begin{abstract}
Abstrak
Penelitian ini bertujuan untuk mengkaji dan mengungkap tentang nilai-nilai sikap tasamuh/toleransi yang sudah ditanamkan oleh jajaran pengurus FKUB Jombang dalam perspektif pendidikan Islam di dua dusun, yakni dusun Ngepeh kecamatan Ngoro dan dusun Subontoro kecamatan Mojoagung. Penelitian ini merupakan penelitian deskriptif kualitatif, subjek dalam penelitian ini adalah pengurus FKUB, tokoh agama dan masyarakat juga perangkat desa/dusun dari 2 kecamatan (Ngepeh Ngoro dan Subontoro Mojoagung). Teknik pengumpulan data yang digunakan adalah pengamatan (observasi partisipan), wawancara dan dokumentasi. Teknik analisis data berlangsung secara simultan yang dilakukan bersamaan dengan proses pengumpulan data dan menarik kesimpulan atau verifikasi. Pemeriksaan keabsahan data menggunakan teknik trianggulasi, member check dan diskusi dengan kolega.

Dengan menggunakan teori "qobul akhor" yang dicetuskan oleh Milad Hanna dan dipertajam dengan teori "al-insan madaniyyun bit-thob' $i$ " oleh Ibnu Khaldun, penelitian ini memiliki beberapa kesimpulan. Berbagai nilainilai tasamuh yang juga disampaikan Mukti Ali juga yang ditemukan di lapangan antara lain: Saling Menghormati dan Menghargai, Saling Mengerti dan Memahami, Kesadaran sikap Adil dan jujur, Mengakui hak orang lain, Berjiwa falsafah pancasila, Silaturrohim/Pertemuan dan Kunjungan kerja. Nilai-nilai sikap toleransi baik intern maupun antar agama benar-benar dapat dirasakan oleh masyarakat lintas agama Jombang dengan terwujudnya kerukunan dan kedamaian pada stabilitas kehidupan kerukunan yang ada pada daerah-daerah yang ada di kabupaten Jombang terfokus pada 2 dusun/desa yang ada di Jombang yakni Ngepeh Rejoagung dan Subontoro Mojotrisno Jombang.
\end{abstract}

Kata kunci: FKUB, Tasamuh, Masyarakat Jombang

\section{Abstract}

This study aims to study and reveal the values of tasamuh / tolerance that have been instilled by the FKUB Jombang management in the perspective of Islamic education in two hamlets, namely Ngepeh hamlet, Ngoro district and Subontoro hamlet, Mojoagung district. This research is a qualitative 
descriptive study, the subjects in this study were FKUB administrators, religious and community leaders as well as village / hamlet officials from 2 sub-districts (Ngepeh Ngoro and Subontoro Mojoagung). The data collection techniques used were observation (participant observation), interviews and documentation. The data analysis technique takes place simultaneously which is carried out simultaneously with the data collection process and draws conclusions or verification. Checking the validity of the data used triangulation techniques, member checks and discussions with colleagues.

By using the theory of "qobul akhor" which was coined by Milad Hanna and sharpened by the theory of "al-insan madaniyyun bit-thob'i" by Ibn Khaldun, this research has several conclusions. Various tasamuh values that were also conveyed by Mukti Ali were also found in the field, including: Mutual Respect and Respect, Mutual Understanding and Understanding, Awareness of Fairness and Honesty, Recognizing the Rights of Others, Having Pancasila Philosophy, Gatherings / Meetings and Work Visits. The values of tolerance both internally and between religions can truly be felt by the interfaith community in Jombang with the realization of harmony and peace in the stability of the life of harmony that exists in areas in Jombang district, focused on 2 hamlets / villages in Jombang. namely Ngepeh Rejoagung and Subontoro Mojotrisno Jombang.

Keywords: FKUB, Tasamuh, Jombang Society

\section{PENDAHULUAN}

FKUB disahkan oleh Bupati Jombang sebagai patner pemerintah dalam menjaga kerukunan serta keharmonisan masyarakat yang beragam agama, etnis dan budaya, FKUB juga merupakan salah satu forum yang berada di bawah naungan kementerian agama yang berperan sebagai mediator dan penyelaras serta memfasilitasi masyarakat dalam hal keberagaman agama baik setingkat kota maupun provinsi yang ada di seluruh Indonesia dengan jumlah pengurus ada 17 orang.

Dalam penelitian ada beberapa ada beberapa tujuan yang akan dicapai yaitu mendiskripsikan, menganalisis dan memberikan interpretasi terhadap: Nilai-nilai sikap tasamuh yang ditanamakan FKUB pada masyarakat dalam menciptakan stabilitas kehidupan kerukunan antar umat beragama dalam persektif pendidikan islam di dusun Ngepeh dan dusun Subontoro Kabupaten Jombang,

\section{METODE PENELITIAN}

Penelitian ini menggunakan metode kualitatif deskriptif serta pendekatan studi kasus teknik pengumplan data dengan observasi, 
wawancara mendalam dan telaah dokumenatsi. Data analisis interaktif melalui tiga bagian reduksi data, penyajian data dan penarikan kesimpulan. Pemeriksaan keabsahan data menggunakan teknik trianggulasi. ${ }^{1}$

\section{PEMBAHASAN}

FKUB yang merupakan sebuah organisasi dan merupakan perpanjangan tangan dari kementerian agama RI untuk menjadikan Negara Indonesia sebagai Negara yang damai dan saling menghormati dengan menjunjung tinggi nilai-nilai kebhinekaan sebagai simbol persatuan Indonesia. Untuk mencapai hal itu maka FKUB Jombang telah melakukan upaya-upaya guna mencapai tujuan dari pada forum kerukunan tersebut yakni dengan menanamkan nilai-nilai sikap tasamuh/toleransi, yang diantaranya;

Sikap saling menghormati dan menghargai. Saling menghormati merupakan sikap yang terpuji juga diantara sikap yang mencerminkan figure yang toleransi, dengan sikap tersebut kerukunan akan terwujud, saling menghormati baik antar agama maupun intern agama juga dari suku dan etnis yang berbeda. $^{2}$ Sebagaimana keterangan yang pneliti dapat bahwasannya FKUB forum kerukunan umat beragama sepakat bersamasama dimulai dari pengurus FKUB yang berjumlah 17 orang sebagai figure public panutan dengan mengajak untuk menjaga kerukunan dan persatuan terkhusus masyarakat Jombang dengan sikap saling menghormati antar sesama bahkan dari agama yang berbeda demi Negara kesatuan republik Indonesia agar terjaga keutuhannya. Juga saling menghormati, menghargai merupakan sikap toleransi yang mampu menjaga kedamaian masyarakat Jombang dan umumnya Negara Indonesia.

Jombang adalah kota santri, identik dengan masyarakat yang beragama islam akan tetapi tidak seluruhnya masyarakat mengerti apa isi dalam agama itu, walaupun Jombang merupakan kota yang terkenal dengan istilah kota santri, tetapi Jombang juga termasuk daerah yang memiliki tingkat pluralitas yang cukup signifikan dari berbagai unsur agama, etnis dan suku, maka dari itu pertahanan untuk menjaga kedamaian dan kerukunan harus tetap diwaspadai yang dalam hal ini dikomandoi oleh FKUB dan dibantu oleh pihak yang berwajib, pemerintah daerah bersama dengan tokoh agama dan masyarakat.

Saling mengerti dan memahami. Saling mengerti merupakan salah satu sikap yang ditanamkan oleh FKUB Jombang demi terciptanya

1 Masykuri Bakri, 2011, Metodologi Penelitian Kualitatif, Malang.

2 M. Tholhah Hasan, 2016, Pendidikan Multicultural Sebagai Opsi Penanggulangan Radikalisme, cetakan 3, (Malang: lembaga penerbitan UNISMA. 
kerukunan intern atau antar umat beragama sehingga menjadikan masyarakat Jombang dengan berbagai suku, etnis dan agama mampu hidup harmonis tidak hanya bermasyarakat tapi juga dalam hidup beragama. memberikan pengertian bahwa sikap saling menghormati dan menghargai antar sesama bisa terwujud dan terbentuk jika didasarkan atas sikap saling mengerti dan sikap memahami antar sesama (tafahum) yang sudah tertanam dalam diri seseorang karena seseorang yang mempunyai sikap menghormati dan menghargai di situ ada sikap mengerti dan faham tentang orang lain. Keterangan data lapangan menunjukkan upaya saling mengerti dengan tanpa memaksakan umat agama lain untuk mengikuti budaya yang berlaku dari pada budaya agamanya dalam rangka untuk menjaga kerukunan umat beragama, sikap saling mengerti serta saling memahami merupakan hal yang sangat penting yang demikian itu dapat terlaksana dengan komitmen seluruh elemen-elemen masyarakat dengan kendali dan turut serta forum kerukunan umat beragama sebagai pelopor kerukunan.

"Agree in disagreement" (setuju di dalam perbedaan) maksudnya adalah perbedaan tidak harus ada permusuhan, karena perbedaan selalu ada di dunia ini, dan perbedaan tidak harus menimbulkan pertentangan. Perbedaan dan keragaman merupakan suatu keniscayaan yang sudah ditentukan oleh sang pencipta namun manusia memiliki tugas dalam menghadapi dan mengkondisikan perbedaan itu yang merupakan juga sebagai ujian, sebagaimana Negara Indonesia merupakan Negara yang penduduknya beragam dari sisi agama, budaya, bahasa dan lain sebagainya. Daerah jombang termasuk bagian yang penduduknya beragam dan bagaimanapun harus dirawat dan dijaga kerukunannya. merupakan tugas bersama untuk menjaga kerukunan dan perdamaian dalam perbedaan tidak hanya di daerah Jombang saja, bahkan Indonesia dan seluruh dunia supaya kondisinya aman dan tidak timbul kehancuran yang akibatnya merugikan diri sendiri dan Negara. ${ }^{3}$

Kejujuran dan keadilan. Salah satu sikap yang amat berharga dalam kehidupan umat manusia adalah kejujuran dan keadilan. Nabi Muhammad saw sebagai suri tauladan dan pedoman akhlak al karimah mengajarkan kepada umatnya untuk selalu berkata jujur dan berlaku adil terhadap sesama umat manusia. Begitu juga diantara sikap dan nilai toleransi yang ditanamkan oleh forum kerukunan umat beragama Jombang yakni sikap jujur dan adil terhadap sesama tidak membeda-bedakan satu sama lain. kondisi itulah sangat dibutuhkan sekali kesadaran akan kejujuran dan

${ }^{3}$ Mohammad Hassan Khalil, 2016. Islam dan Keselamatan Pemeluk Agama Lain. Bandung: PT. Mizan Pustaka. 
keadilan dengan tidak membedakan suku, agama, etnis dan lain sebagainya, apalagi dari penuturan informan di atas, islam adalah agama yang selalu menebar kasih terhadap semua yang ada di alam ini rahmatan lil 'alamin, selalu mengedepankan asas kemanusiaan, yang Negara kita dengan terus mengupayakan adanya kedamaian dengan sikap tolerasiannya dan saling menghargai terhadap sesama dan tidak membedakan penduduk warganya semua diberlakukan sama atas haknya. Sebagaimana keterangan Indonesia Negara kita telah banyak berjasa dalam ikut partisipasi dalam mendamaikan sebagian Negara yang dalam konflik.

Betapa pentingnya sikap adil dan jujur yang diterapkan sekaligus ditanamkan oleh FKUB kepada para pengurus FKUB dan para tokoh agama lintas agama juga pada masyarakat Jombang untuk mencapai kerukunan, kedamaian dan keharmonisan masyarakat Jombang terlebih pada momen pilkada yang setiap calon mempunyai para pendukung yang terkadang potensi untuk menjadikan suasana daerah hangat bahkan memanas karena berebut dukungan, juga dalam suasana itulah yang sangat rawan adu domba terlebih waspada dari media sosial atau hoax.

Mengakui hak orang lain. Dalam hubungannya dengan agama dan kepercayaan, toleransi berarti menghargai, membiarkan, membolehkan kepercayaan agama yang berbeda itu tetap ada, walaupun berbeda dengan agama dan kepercayaan seseorang. Toleransi tidak berarti bahwa seseorang harus melepaskan kepercayaannya atau ajaran agamanya karena berbeda dengan yang lain, tetapi mengizinkan perbedaan itu tetap ada. Toleransi menjadi perantara (wasilah) terciptanya kebebasan beragama dengan tanda kutip, apabila kata tersebut diterapkan pada orang pertama kepada orang kedua, ketiga dan seterusnya. Dalam artian, tatkala seseorang ingin menggunakan hak kebebasannya, ia harus terlebih dulu bertanya pada diri sendiri, tentang apakah kita telah melaksanakan kewajiban untuk menghormati kebebasan orang lain? Sebelum kita menerima hak kita untuk bebas dan dihormati

Sikap toleransi yang cukup luas cakupannya, yakni toleransi tidak hanya menghormati dan menghargai saja akan tetapi juga memberikan atau membiarkan hak-hak orang lain yang berbeda di sekitar kita dengan contoh yang disampaikan informan di atas yaitu tidak memaksakan keyakinan karena agama adalah hak pilihan setiap orang yang Negara Indonesia sudah diberi kebebasan untuk memilih agama yang diakui oleh Negara (Islam, Kristen, Katolik, Hindu, Budha Dan Konghucu) yang tersebut tertera dalam UUD1945 dinyatakan bahwa tiap-tiap penduduk diberikan kebebasan untuk memilih dan mempraktikkan dan menjamin semuanya akan kebebasan untuk menyembah menurut agama atau kepercayaannya. 
Agama-agama akan semakin moderat jika mampu mempersandingkan kebebasan dan toleransi. Kebebasan merupakan hak setiap individu dan kelompok yang harus dijaga dan dihormati, sedang toleransi adalah kewajiban agama-agama dalam hidup bersama

Menjiwai falsafah pancasila. Dalam jiwa terdapat nilai-nilai kebaikan yakni berperan memberi gerak dan dinamika serta membimbing masyarakat pancasila, yang lahirnya pancasila bersamaan dengan adanya bangsa Indonesia. kegiatan seminar kebangsaan 2017 bersama FKUB menunjukkan adanya pembinaan serta penanaman pada masyarakat yang dipelopori oleh forum kerukunan umat beragama Jombang guna mewujudkan masyarakat untuk selalu mencintai tanah air Indonesia dan bangga serta bersyukur sebagai bangsa indonesia dengan mengamalkan dan mengikuti prinsip dasar pancasila sebagai idiologi Negara.

Kunjungan dan silaturrohim. Untuk memupuk sikap tasamuh lintas agama FKUB Jombang sangat sering mengadakan pertemuan dan kunjungan disamping rapat rutin, semua itu bertujuan untuk menambah keeratan dan kerekatan antar pengurus FKUB juga antar tokoh lintas agama juga ormas yang ada di Jombang. pengurus FKUB Jombang mengupayakan untuk saling bertemu sebagai sarana kunjungan silaturrohim para pengurus FKUB sendiri, tokoh masyarakat toma juga tokoh agama toga Jombang, sebagaimana yang dituturkan dalam wawancara hal itu bertujuan untuk menambah kerekatan serta keharmonisan antar pengurus juga antar tokoh lintas agama, pertemuan-pertemuan itu juga dapat dijadikan sebagai sarana untuk komunikasi dengan beberapa kelakar yang dapat mencairkan suasana serta menghilangkan kecurigaan-kecurigaan adakalanya membahas perkembangan kerukunan yang ada di Jombang dengan beberapa solusi dan penyelesaian dari para tokoh lintas agama.

Silaturrohim serta kunjungan FKUB Jombang tidak cukup hanya dengan para pengurus tokoh lintas agama dan tokoh masyarakat Jombang saja, namun juga mengadakan kunjungan dan silaturrohim dengan pengurus FKUB wilayah daerah lain. bahwasannya silaturrohim itu tidak hanya terbatas dalam wilayah Jombang pengurus FKUB tokoh lintas agama dan tokoh masyarakat saja akan tetapi kunjungan dan silaturrrohim FKUB Jombang tersebut sudah sampai pada lintas daerah antar pengurus FKUB dengan tujuan silaturrohim dan study tour, memupuk tali persaudaraan juga yang terpenting adanya study berbagi keilmuan dan pengalaman antar pengurus FKUB yang dapat dijadikan sebagai pedoman untuk melangkah dan menjalankan roda kerukunan yang ada di masing-masing daerah termasuk Jombang, dan agar tercipta Indonesia yang toleran serta damai dan rukun dalam kemajemukan sebagaimana semboyan bhinneka tunggal ika berbeda-beda tapi tetap satu jua 
Dalam penanaman sikap tasamuh yang dilaksanakan oleh forum kerukunan umat beragama FKUB Jombang pada masyarakat Jombang yakni yang terfokus pada 2 kecamatan dari 2 desa (dusun Ngepeh dan dusun Subontoro) dan juga nilai-nilai sikap tasamuh/toleransi yang sudah terbudaya ada banyak hal yang relevan dengan teori yang penulis lakukan. Konsep qobul akhor menerima orang lain walau berbeda dengan kita, yang digagas oleh Milad Hanna diinternalisasikan oleh forum kerukunan umat beragama FKUB Jombang melalui penanaman nilai-nilai sikap tasamuh dengan dialog, muasyawarah juga kunjungan dan silaturrohim pada masyarakat Jombang

Dalam penanaman sikap tasamuh/toleransi yang dilakukan oleh FKUB Jombang dalam berbagai dialog dan pertemuan peneliti menemukan beberapa nilai-nilai sikap tasamuh yang ditanamkan melalui para pengurus tokoh agama dan masyarakat yang nantinya disampaikan kepada warga dan lingkungan masing-masing diantaranya saling menghormati dan menghargai ihtirom sebagaimana yang peneliti temukan di lokasi penelitian yakni pada pertemuan-pertemuan yang melibatkan seluruh pengurus FKUB juga tokoh lintas agama serta tokoh masyarakat.

FKUB merupakan forum kerukunan masyarakat maka dalam hidup bermasyarakat yang terdiri dari berbagai perbedaan dibutuhkan sikap toleransi sehingga dapat tercipta hidup rukun. Perbedaan agama yang terdapat di masyarakat haruslah disikapi dengan bertoleransi yaitu saling menghargai dan menghormati antar umat beragama. Hal tersebut seperti yang dikatakan Hans Kung, bahwa tidak ada perdamaian sesama manusia tanpa ada perdamaian antar agama. Kehidupan masyarakat yang rukun dan sejahtera adalah bergantung pada masyarakatnnya. Ketika setiap orang dapat saling mengerti antara satu sama lain yaitu mengerti perbedaan agama yang ada dan selalu menghormati serta menghargai maka perdamaian hidup dapat tercapai.

Nilai-nilai tasamuh yang ditanamkan oleh FKUB pada masyarakat Jombang dalam kehidupan sehari-hari antara lain; saling menghormati dan menghargai yakni dalam hal ini seluruh masyarakat menerapkan sikap saling menghormati satu dengan yang lain dengan tanpa memandang perbedaan suku ras dan agama atau status strata sosial, dengan sikap tersebut, maka kerukunan masyarakat Jombang akan senantiasa terwujud.

Sikap saling menghormati atas dasar musawah persamaan dalam pergaulan dengan saling menghormati yang telah ditanamkan oleh FKUB pada masyarakat Jombang dengan tujuan utama yakni menciptakan Jombang harmonis terus diupayakan oleh para pengurus FKUB Jombang.

Dari sinilah perlunya sekaligus menanamkan sikap saling saling menghormati ihtirom yang mana Ihtiram artinya saling menghargai atau 
saling hormat menghormati kepada sesama manusia. Saling harga menghargai adalah satu sikap yang harus dimiliki oleh setiap muslim sebagai wujud dari Akhlaqul mahmudah. Sebagaimana Islam sangat menekankan pada dua dimensi nilai yang harus selalu diwujudkan yaitu akhlaq yang terpuji dan aqidah atau keimanan yang benar, dua-duanya harus seiring sejalan. Aqidah yang benar akan membuahkan akhlaq yang baik. Akhlaq yang baik harus berakar pada aqidah yang benar.

Salah satu sifat yang mesti diwujudkan dalam kehidupan sehari-hari ialah saling menghargai kepada sesama manusia dengan berlaku sopan, tawadhu, tasamuh, muru'ah (menjaga harga diri), pemaaf, menepati janji, berlaku 'adil dan lain sebagainya. Perhatikan sabda Rasulullah :

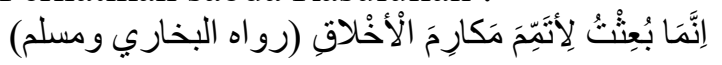

Artinya: "Sesungguhnya aku diutus untuk menyempurnakan akhlaq yang mulia" (HR .Ahmad dan Baihaqi).

Dari hadits di atas dijelaskan bahwa dalam pergaulan sehari-hari kita dituntut untuk menampakkan akhlaq yang mulia dalam tutur kata dan perilaku dan bahkan menjadi syarat kesempurnaan Iman seorang mukmin baik kepada sesama muslim maupun selain (non) muslim

Saling mengerti dan memahami atau dengan istilah kata "tafahum" artinya saling pengertian. Suatu realitas kehidupan sosial menunjukkan bahwa di dalam masyarakat, kita banyak menemukan apa yang kita sebut multi perbedaan, seperti perbedaan dalam keyakinan dan beribadah, perbedaan dalam adat istiadat, perbedaan dalam bahasa, perbedaan pendapat, dan sebagainya. Semua perbedaan itu bukan harus dibantah dan dipertentangkan, tetapi harus saling dipahami. Kita harus menghadapinya dengan cara tafahum terhadap segala perbedaan yang ada.

Di lapangan peneliti menemukan penerapan nilai sikap tasamuh yang ditanamkan oleh FKUB Jombang sebagaimana nilai sikap tasamuh yang pertama di atas, maka nilai sikap tasamuh yang kedua yang ditanamkan oleh FKUB Jombang adalah sikap saling mengerti dan memahami demi terciptanya kerukunan intern atau antar umat beragama sehingga menjadikan masyarakat Jombang dengan berbagai suku, etnis dan agama mampu hidup harmonis tidak hanya bermasyarakat tapi juga dalam hidup beragama. Sikap saling memahami termasuk berusaha mengetahui secara mendalam kondisi orang lain, Upaya untuk saling memahami dan mengetahui secara mendalam keadaan secara jelas, baik yang menyangkut kepribadian maupun keada'an keluarga, dengan adanya saling memahami dengan mengerti kondisi orang lain baik antar warga tetangga teman yang seagama maupun berbeda agama suku dan etnis, menjadikan seseorang mempunyai sikap toleransi dan timbulnya sikap rasa kasih sayang dengan uluran pertolongan (sikap menolong). 
Upaya saling memahami tafahum diawali dengan sikap saling mengenal, dengan mengenal maka akan saling menyayangi dan memahami. tentang pendewasaan iman yang dilakukan dalam proses pembelajaran majelis-majelis, forum sharing yang dilakukan dalam kelompok-kelompok kecil. Di situlah substansi pengajaran ditekankan akan pentingnya hidup berdampingan secara harmonis dengan masyarakat yang berbeda suku, agama dan strata sosial. Juga penekanan untuk menjalin kerjasama antar umat beragama yang terkait masalah-masalah kemanusiaan. Dengan proses lanjutan dalam pematangan berfikir umat dengan cara menggalakkan dialog lintas agama secara berkelanjutan. Dialog agama yang bukan sekedar upaya pembelaan agama tetapi dialog yang condong pada suatu upaya memahami ekspresi keimanan agama-agama.

Dari sini peneliti memberikan analisis bahwa sikap saling menghormati dan menghargai antar sesama bisa terwujud dan terbentuk jika didasarkan atas sikap saling mengerti dan sikap memahami antar sesama (tafahum) yang sudah tertanam dalam diri seseorang karena seseorang yang mempunyai sikap menghormati dan menghargai di situ ada sikap mengerti dan faham tentang orang lain.

Jauh dari pada itu FKUB menanamkan sikap di atas merupakan potret kerukunan inter dan antar umat beragama yang amat indah dan menyejukkan. Toleransi yang dibangun oleh FKUB pada semua warga siapapun mereka, bukan sekedar toleransi lahiriah, melainkan toleransi yang lahir dari nurani paling dalam. Saling berlomba-lomba dalam ketulusan dan kejernihan batin.

Daerah jombang termasuk bagian yang penduduknya beragam dan bagaimanapun harus dirawat dan dijaga kerukunannya, kerukunan dan perdamaian memang semestinya harus dijaga dan dirawat sebagaimana jombang yang warga dan penduduknya sangat beraneka ragam, karena keragaman yang ada dalam kehidupan ini merupakan anugerah yang harus disyukuri dan dijaga. FKUB selaku pihak yang diberi amanah dan wewenang untuk mempromotori dan mengkordinasi jombang agar terjaga kerukunan dan kedamaian warga masyarakat jombang baik antar agama maupun intern agama.

Kemudian pada dasarnya menjaga kerukunan dan kedamaian merupakan dan memang tugas masyarakat bersama tidak hanya di daerah jombang saja, bahkan Indonesia dan seluruh dunia supaya kondisinya aman dan tidak timbul kehancuran yang akibatnya merugikan diri sendiri dan Negara yang mana dalam hal ini dikordinatori oleh FKUB di masingmasing daerah dan propinsi diseluruh Indonesia.

Kemudian nilai Sikap tasamuh yang ke tiga yang ditanamkan oleh FKUB Jombang yakni menanamkan sikap adil dan jujur pada masyarakat 
Jombang sebagaimana penanaman sikap toleransi yang lain yakni sebagaimana melalui tokoh masyarakat dan juga interaksi langsung dengan warga masyarakat, dalam penanaman sikap adil fkub Jombang memberikan pelayanan kepada masyarakat lintas agama sebagaimana porsinya. Sebagaimana Nurcholis Madjid adil berasal bahasa arab yang berarti sikap tengah-tengah yang berkeseimbangan, dan jujur. Secara terminologis adil bermakna suatu sikap bebas diskriminasi dan ketidakjujuran. Dengan demikian orang yang berlaku adil adalah orang yang prilakunya sesuai dengan standar hokum baik hokum agama, hokum positif (hokum Negara) maupun hokum sosial dan hokum adat istiadat yang berlaku

Pada ayat di atas terdapat panggilan pada kekhususan bagi orang yang iman kepada Allah dengan memberikan arahan perintah untuk menjadi penegak keadilan dan menjadi saksi yang adil al-qisth, dan ada yang lebih menarik lagi yakni ada sebuah peringatan keras tentang jangan sampai dengan adanya sikap kebencian terhadap suatu golongan lantas mengahalangi kita dalam melaksanakan sikap keadilan, maka dalam hal ini forum kerukunan umat beragama FKUB Jombang sudah memulainya dari melakukan pendekatan-pendekatan yang sifatnya menghindari permusuhan kebencian kecurigaan yang mengakibatkan ada sikap tidak terpuji terhadap salah satu golongan yang dianggap dibenci. Diantara pendekatannya adalah melakukan dialog dan pertemuan, silaturrohim, saling tolong menolong, dengan demikian antar pengurus juga tokoh lintas agama akan muncul taa'ruf saling kenal, tafahum saling mengerti dan memahami dan ta'awun saling tolong menolong dan hilanglah rasa kebencian itu dan FKUB melengkapinya dengan penanaman sikap keadilan dan kejujuran terhadap sesama.

Dalam hal ini semua manusia mempunyai hak diantaranya yang telah dijamin kebebasannya oleh Negara di antaranya hak untuk hidup, hak untuk memeluk agama sesuai dengan kepercayaan yang diyakini, dari situ FKUB mendukung program pemerintah dalam menjaga kerukunan dengan menanamkan sikap toleransi yang diantara nilai sikapnya yakni mengakui hak orang lain.

Sikap tasamuh/toleransi adalah ajaran islam yang sudah dipraktekkan dan disuritauladankan oleh baginda Rasulullah Saw, Tujuan tentang tasamuh atau toleransi dalam kehidupan beragama yang ditawarkan oleh Islam begitu sederhana dan rasional. Islam mewajibkan para pemeluknya membentuk batas yang tegas dalam hal akidah dan kepercayaan, sambil tetap melindungi prinsip penghargaan terhadap keberadaan para pemeluk agama lain dan melindungi hak-hak mereka sebagai pribadi dan anggota masyarakat. Pembatasan yang jelas dalam hal 
akidah atau kepercayaan ini merupakan upaya Islam untuk menjaga para pemeluknya agar tidak terjebak pada sinkretisme.

Di mata Allah swt manusia mempunyai derajat yang sama sama hanya ketaqwaannya yang membedakan derajat di sisi-Nya, dengan persamaan derajat manusia maka hak yang diterima oleh disampaikan oleh mereka juga sama tidak ada yang berbeda, Allah swt dalam Al-Quran dengan panggilan yaa banii aadama wahai keturunan adam (manusia)

Bermula dari ta'aruf antar tokoh lintas agama, yang memunculkan saling mengenal, lantas tumbuh saling paham dan sering bertemu dan berkomunikasi serta berinteraksi kemudian terwujudlah saling mengerti dan memahami tafahum bersamaan dengan itu akan muncul rasa kasih sayang erat hubungan diantara keduanya sebagaimana saudara kandung ada rasa kangen jika lama tidak bertemu, pada akhirnya akan tumbuh rasa taawun saling menolong diantara mereka sewaktu ada diantara mereka yang menderita ada tertimpa musibah, hal itu yang sangat penting untuk memupuk kerukunan dan keharmonisan antara masyarakat yang hitrogin sebagaimana masyarakat Jombang, juga sudah ditanamkan oleh FKUB Jombang.

Dalam rangka untuk menjaga persatuan dan kesatuan NKRI juga dalam menjaga stabilitas kerukunan masayarakat, warga negara Indonesia sudah seharusnya untuk menjiwai dan menjadikannya sebagai pedoman Negara yakni pancasila, dalam hal ini juga FKUB Jombang terus menerus berupaya untuk menjaga kerukunan dan kedamaian masyarakat Jombang mengingat dan mengantisipasi akan golongan-golongan yang anti dan menentang pancasila, dalam penanamannya FKUB menempuhnya dengan berbagai cara diantaranya dengan mengadakan pertemuan untuk pembinaan mengenai dasar Negara pancasila

Dalam pelaksanaanya forum kerukunan umat beragama selalu menyampaikan akan kerukunan yang didasarkan pancasila sebagai dasar Negara juga bhinneka tunggal ika, akan pentingnya kerukunan yang dirajut bersama-sama dengan mengamalkan butir-butir pancasila sdebagai pedoman dasar Negara maka nilai sikap tasamuh sudah tertanam dalam jiwa masyarakat. Apalagi dasar pancasila sangat tidak bertentangan dengan nilainilai agama islam yang tertera dalam al-Quran surat ali imron 64, jadi kerukunan dan keharmonisan yang diupayakan oleh FKUB melalui penanaman sikap tasamuh yang diantara nilai toleransinya yaitu menjiwai dasar Negara pancasila yang demikian sangat sesuai dengan pendidikan islam untuk selalu mengikuti al-Quran sebagai pedoman bagi umat muslim ${ }^{4}$.

\footnotetext{
${ }^{4}$ Al Quran dan Terjemahan, 2010. Departemen Agama, Jakarta.
} 
Kegiatan kunjungan dan silaturrohim merupakan tradisi dan agenda rutin yang sudah sangat sering dilakukan oleh forum kerukunan umat beragama Jombang dalam penanaman sikap toleransinya karena diantara nilai sikap toleransi yang sangat tampak yaitu silaturrohim dan kunjungan antar pengurus FKUB khususnya sekali waktu pengurus FKUB konghucu, kristen dan hindu mengunjungi kediaman atau tempat ibadah pengurus FKUB muslim.

Dalam buku kumpulan tanya jawab keagamaan yang ditulis oleh PISS pustaka ilmu sunni salafiyah (2015:7597) disebutkan bahwa kalimat silaturrohim صلة الرحم sama artinya dengan silaturrohmi hanya saja penyebutan silaturrohmi kurang tepat dan yang tepat silaturrohim. Yang kalimat di atas hanya penyebutan dalam hal ijtihad lughowi saja. Adapun

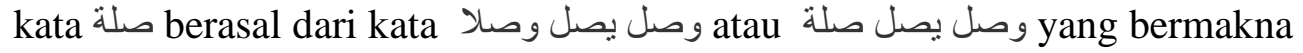
sambung (al washl) lawan dari pada putus (al qoth'). Sebagaimana pada pendapat ibn 'athir yang dimaksud silaturrohim berbaik-baik kepada kerabat dekat yang masih ada hubungan keluarga.

$$
\text { النقول الامام ابن الاثير "صلة الرحيم هي الاحسان الى الأقربين من ذوي }
$$

Dalam hal ini pengurus FKUB serutin mungkin mengadakan pertemuan silaturrohim serta kunjungan lintas agama, hal itu bertujuan untuk menambah kedekatan dan keakraban antar tokoh lintas agama yang nantinya akan dibawa dan disampaikan angin segar yang berupa keharmonisan tersebut kepada warga dan umatnya masing-masing. Dalam kunjungan itu adakalanya ke gereja, pure, kelenteng juga ke masjid baik itu dari NU, Muhammadiyah dan juga LDII, dari silaturrohim tersebut akan terlihat tali silaturrohim yang sangat berarti dan dijadikan sebagai ajang kerukunan dalam suasana yang toleransi, pengurus FKUB mengupayakan dalam kunjungan tersebut tidak adanya diskriminasi, membedakan itu kristiani, hindu, budha atau konghucu.

Upaya FKUB Jombang terus menerus dilakukan demi mewujudkan kerukunan masyarakat dengan berbagai cara yang seluruhnya bermuara dari adanya sikap tasamuh yang dikembangkan dalam nilai-nilai yang ditanamkan oleh pengurus FKUB sendiri dan juga pada seluruh masyarakat Jombang melalui tokoh lintas agama dan tokoh masyarakat.

Dari nilai toleransi yakni budaya silaturrohim yang ditanamkan oleh FKUB pada masyarakat Jombang sebagaimana sabda Rasulullah Saw.:

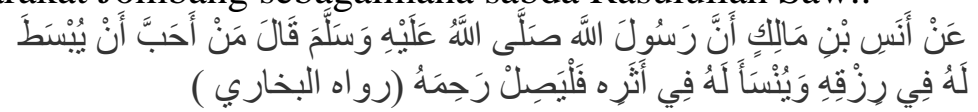

Dari Anas bin Malik RA bahwa Rasulullah SAW bersabda, "Barang siapa yang ingin dilapangkan pintu rezeki untuknya dan dipanjangkan umurnya, hendaknya ia menyambung silaturrohim" (HR. Bukhori). 
Pada hadits di atas memberikan pencerahan tentang keutamaan silaturrohim yang mana dalam silaturrohim ada 2 keutamaan yakni yang pertama dilapangkan rizkinya dan ke dua dipanjangkan usianya. Jelas sudah dari apa yang dilakukan oleh FKUB dalam membina masyarakat Jombang yang rukun dan damai. Bahkan saking pentingnya menyambung tali silaturrohim sampai-sampai ada suatu hadits yang menerangkan bahawa Rasulullah saw. tidak mengakui seseorang sebagai umatnya apabila sengaja memutus silaturrohim

\section{KESIMPULAN}

Manusia adalah makhluk yang senantiasa berinteraksi antara satu dengan yang lain, dengan meminjam istilah Ibnu Khaldun al insan madaniyyun bit thob' $i$ yakni manusia adalah makhluk yang berperadaban maka pentingnya perkumpulan persatuan kebersamaan dan kasih sayang. Nilai-nilai tersebut merupakan sebuah keniscayaan untuk membangun toleransi diantara sesama umat.

Teori yang disampaikan oleh Milad Hanna yang menawarkan budaya menerima orang lain dalam kebaikan dan kebenaran (qobul akhar) sebagai manifestasi dari inklusivisme dan pluralisme. Menurutnya qobul akhar sangat urgen untuk memperkecil volume fanatisme dan kebencian terhadap budaya dan pemikiran orang lain, baik dalam wilayah internal maupun eksternal.

Berdasarkan pada fokus penelitian serta temuan di lapangan tentang forum kerukunan umat beragama dalam penanaman sikap tasamuh pada masyarakat (Kajian Kritis Stabilitas Kehidupan Kerukunan Antar Umat Beragama Dalam Perspektif Pendidikan Islam Di Dusun Ngepeh dan Dusun Subontoro Kabupaten Jombang), maka nilai-nilai sikap tasamuh yang ditanamkan oleh fkub jombang ialah; sikap Saling Menghormati dan Menghargai (Ihtirom) Saling Mengerti dan Memahami (Tafahum) Agree in disagreement Kesadaran Bersikap Adil Dan Jujur (Al-Adl Wa Al-Shidq) Mengakui Hak Orang Lain Berjiwa Falsafah Pancasila Kunjungan dan Silaturrohim.

Upaya penanaman seluruh nilai sikap tasamuh yang dilakukan oleh FKUB Jombang tersebut dengan harapan terwujudnya masyarakat Indonesia dan Jombang khususnya menjadi masayarakat yang damai harmonis untuk menjaga kekuatan NKRI.

\section{DAFTAR PUSTAKA}

Al Quran dan Terjemahan, 2010. Departemen Agama, Jakarta.

Abdul Karim, 2007. Islam Nusantara, Yogyakarta: Pustaka Book Publiser. 
Abdurrahman Wahid, 2006. Islamku Islam Anda Islam Kita. Jakarta: TheWahid Institute.

Ainul Yaqin, 2005. Pendidikan Multikultural Cross-Cultural Understanding Untuk Demokrasi dan Keadilan: Pilar Media.

Adnan Buyung Nasution, 1995. Aspirasi pemerintahan konstitusional di Indonesia: studi sosio-legal atas konstitusi 1956-1959, Jakarta, Graffiti, 1995.

Ahsanul Kholikin, 2010. Jurnal penelitian "Pendirian Rumah Ibadahdalam Perspektif PBM Nomo 9 dan 8 Tahun 2006 (Kasus Pecabutan IMB Gereja HKBP Pangkalan Jati Gandul, Kec. Limo Kota Depok)" dalam jurnal harmoni Vol. IX Nomor 35 Juli-September.

Andayani, 2015. Problema dan aksioma dalam metodolgi pembelajaran bahasa Indonesia, Yogyakarta, penerbit deepublish.

Aninomus, 2007. Peraturan Bersama Menteri Agama dan Menteri dalam negeri No.9/no.8 tahun 2006, FKUB, Pekanbaru.

A. Malik Fadjar, 1999. Reorientasi pendidikan Islam Jakarta: Fajar Dunia. A. Hakim Bashori Dan Moh. Saleh Isre (Ed), 2004. Fungsi Sosial Rumah Ibadah: dari Berbagai Agama dalam Perspektif Kerukunan Umat Beragama, Puslitbang Kehidupan Beragama, Badan Litbang dan Diklat Keagamaan Departemen Agama).

Ahmad Suaedy, "Kondisi Minoritas Beragama dan Berkeyakinan di Indonesia dan Tantangan Ke Depan". Makalah disampaikan dalam "Seminar Nasional Hak Asasi Manusia, Kerukunan Kehidupan Beragama dan Berkeyakinan di Indonesia," di Komnas HAM, Jakarta 29 Juli 2010.

Ahmad Syafii Maarif, 2015. "Islam Dalam Bingkai Keindonesiaan Dan Kemanusiaan : Sebuah Refleksi Sejarah. Bandung: PT. Mizan Pustaka.

Bagus Takwin, 2005. Kesadaran Plural sebuah sintesis Rasionalitas dan Kehendak Bebas, Yogyakarta: Jalasutra.

Benyamin F Intan, "Rumah Ibadah dan Hegemoni Negara”, Suara Pembaruan, 3 Agustus 2009.

Burhan Bungin, 2003. Analisis Data Penelitian Kualitatif, Jakarta: PT Raja Grafindo Persada.

Budhy Munawar Rohman dan Elza Peldi Taher, 2013. Satu Menit Pencerahan Nurcholish Madjid, Jakarta: Paramadina.

Burhanuddin Daya dan Beck, Herman Leonard, red. 2004. Agama Dialogis Merada Dialektika Idealitas dan Realitas Hubungan Antaragama. Yogyakarta: Mataram-Minang Lintas Budaya.

Choirul Mahfud, 2014. Pendidikan Multikultural, Yogyakarta: Pustaka Pelajar. 
Irwan Masduqi, 2011. Berislam Secara Toleran Teologi Kerukunan Umat Beragama, Bandung : PT. Mizan Pustaka

Lexy Moleong, 2000. Metodologi Penelitian Kualitatif ,Bandung: Rosdakarya.

M. Ngalim Purwanto, 2005. Ilmu Pendidikan Teoritis, dan Praktis, Bandung: PT Remaja Rosda Karya .

Masykuri Bakri, 2011, Metodologi Penelitian Kualitatif, Malang.

Mohammad Hassan Khalil, 2016. Islam dan Keselamatan Pemeluk Agama Lain. Bandung: PT. Mizan Pustaka.

Mun'im sirry, 2013. Polemik Kitab Suci, Tafsir Reformasi Atas Kritik Al Quran Terhadap Agama Lain. Jakarta: PT. Gramedia Pustaka Utama.

M. Tholhah Hasan, 2016, Pendidikan Multicultural Sebagai Opsi Penanggulangan Radikalisme, cetakan 3, (Malang: lembaga penerbitan UNISMA.

Zuhairi misyrawi, 2007. Al-Quran Kitab Toleransi Inklusivisme, Pluralism Dan Multikulturalisme, Jakarta: Penerbit Fitrah. 